\section{$2 \cdot 4 \cdot 3$ 妨害元素 分光定性により検出されなかっ} た成分については特に考慮しなかった。タリウムを含ま ぬ場合湓酸溶液 $(8 M)-\mathrm{MIBK}$ 法によりインジウムを 抽出除去しもよい.

銅は $20 \mu \mathrm{g}$ 共存しても妨害しなかった。

2.4 .4 分析例 2.2 .6 および 2.4 .1 に従って, $\mathrm{Y}$ 社製 99.95\% インジウム中の鉛它定量して Table XIV D結果芫得た。

Table XIV Determinatito of lead

\begin{tabular}{ccccc}
\hline \hline Method & \multicolumn{3}{c}{ Pb found $(\mathrm{ppm})$} \\
\hline Colorimetry : Procedure-(1) & 16.4 & 14.6 & \\
& Procedure-(2) & 17.0 & 15.9 & \\
& 14.9 & 15.4 & 15.4 \\
Polarography : & 18.2 & 16.6 & \\
\hline
\end{tabular}

終りに，本实験を行なうにあたり，ご指導を晹わり発 表を許可された中俊一所長ならでに分光定性をされた 土淵 䀡氏に謝意を表します。

\section{交献}

1）古賀俊 - : 工業レアメタル，No. 6, 46 (1957).

2) アルム出版社編：工業レアメタル, No. 13, 17 (1960).

3) 斉 加美彦: ポーラログラフィー, 8, 107 (1960).

4) 斎 加美彦, 西野一雄 : 本誌, 9, 557 (1960).

5）安盛善一，西村隆雄：同上，9，37(1960).

6) 安盛滂一, 江口正: 同上, 9, 127 (1960).
7）上原博義：ポーラログラフィー，7，81 (1959).

8) 斎 加美彦: 同上, 7,70 (1959).

9) 田島信雄, 黒部森司：本誌，9，801 (1960).

10) 田島信雄, 寺田弘明, 黒部森司 : 同上, 11, 69 (1962).

11）上原博義：ポーラログラフィー, 7, 86 (1959).

12) 白井ひで子：本誌，9，206 (1960).

13) F. A. Poh1, W. Bonsels : Z. anal. Chem., 161, 108 (1958).

14) W. Doll, H. Specker : ibid., 161, 354 (1958).

15) R. Bock, H. Kusche, E. Bock : ibid., 138, 167 (1953).

16) 田島信雄, 寺田弘明, 黒部森司 : 本誌, 11, 69 (1962).

Polarographic and photometric determination of lead, cadmium and zinc in highly pure indium. (Analysis of impurities in purest indium. I.) Koichi Nishimura and Teruo Imai (Sumitomo Metal Mining Co., Tokyo Laboratory, Musashino, Tokyo)

After the separation of indium from $5 \mathrm{~N}$ hydrobromic acid solution with iso-propyl ether extraction, the aqueous solution was heated with nitric acid or nitric and perchloric acids to dryness.

The residue was dissolved in phosphoric acid $(4+50)$, and subjected to the square wave polarographic determination of lead and cadmium $(-0.5 \sim-1.1 \mathrm{~V}$ vs. $\mathrm{Hg})$ and $z$ inc $(-1.1 \sim-1.6 \mathrm{~V}$ vs. $\mathrm{Hg})$.

Lead was determined also by colorimetry with dithizone-benzene extraction, but the results were a little lower.

(Received Dec. 9, 1963)

\title{
銅のエチレンジアミンテトラ酢酸キレート 化合物によるインジウムの間接光度定量
}

\author{
大西 寛，永井 斉*
}

銿 (II) 打よびインジウム (III) のエチレンジアミンテトラ眽酸 $\left(\mathrm{H}_{4} \mathrm{Y}\right)$ のキレート化合物のみかけの生 成定数のあいだには大きな差がある.そのため銅のエチレンジアミンテトラ酢酸キレート $\left(\mathrm{CuY}^{2}\right.$ ○であ らわす) にインジウムを加え机，置換によって，インジウムのキレート(InY-) が生成し, 銅イオン が遊離される. $\mathrm{CuY}^{2-}$ の $740 \mathrm{~m} \mu$ に打ける吸光度の減少からインジウムを定量することができる.

吸光度の減少を測定するには，インジウムを含む試料溶液を対照として， $\mathrm{CuY}^{2-}$ のみを含む試薬ブ ランクの吸光度を測定する方式を用いた。

$\mathrm{pH} 4.3$ に打いて, $100 \mathrm{mg}$ の $\mathrm{Na}_{2} \mathrm{CuY} \cdot 4 \mathrm{H}_{2} \mathrm{O}$ を用いて, $25 \mathrm{ml}$ 中 5 ～ $20 \mathrm{mg}$ のインジウムを精度 よく定量することができる。 


\section{1 まえがき}

銅(II) とエチレンジアミンテトラ酢酸 (EDTA; $\mathrm{H}_{4} \mathrm{Y}$ であらわす）のキレート化合物は 700〜750 $\mathrm{m} \mu$ に光吸 収を示す．この性質を利用して，銅の光度定量法がつく られた1)。

$20^{\circ} \mathrm{C}$ ，イオン強度 0.1 亿拈ける銅 (II) およびインジ ウム (III) の EDTA キレートの生成定数 $\left(K_{\mathrm{MY}}\right)$ の対数 はそれぞれ 18.80 および 24.9 である22. $\mathrm{pH} 4$ 亿おけ るタかけのキレート生成定数 $\left(K_{\mathrm{H}}\right)$ の対数は銅-EDTA キレートに対して 10.36，インジウム-EDTA キレート に対して 16.5 となる3).

いま, $\mathrm{pH} 4$ に沶いて, 銅のエチレンジアミンテトラ 酩酸キレートにインジウムイオンを加光ると，

$$
\mathrm{In}^{3+}+\mathrm{CuY}^{2-} \rightleftarrows \mathrm{In} \mathrm{Y}^{-}+\mathrm{Cu}^{2+}
$$

の反応が右へ進むであろう。もし InY- と $\mathrm{Cu}^{2+}$ が 700〜 750 m $\mu$ に光吸収を示さなければ， $\mathrm{CuY}^{2-}$ による 吸光度の減少を測定することによりインジウムの定量が 可能であろうと考光た。このような銅(II) のエチレンジ アミンテトラ酶酸キレートの置換を利用した光度定量法 はまだ報告されていない。

\section{2 装置および試薬}

\section{$2 \cdot 1$ 装}

吸光度の測定は日立 EPU-2A 分光光度計, $1 \mathrm{~cm} セ ル$ を用いて行なった. $\mathrm{pH}$ の測定には堀場 Model M-3 pH メーターを使用した.

\section{$2 \cdot 2$ 試 薬}

銅のエチンンジアミンテトラ酶酸キレート(以下 $\mathrm{Cu}-$ EDTA であらわす）溶液をつぎの二つの方法によって 調製した。どちらの場合も同じインジウムの結果を与え た.

（1）分光分析の電極用の純粋な銅 $1.4 \mathrm{~g}$ を正確には かりとり， $1: 1$ 硝酸 $20 \mathrm{~m} l$ 亿溶解した. 溶液を蒸発し て過剩の酸を除いたのち水約 $200 \mathrm{~m} l$ 亿溶解した。

別化特級 EDTA $2 \mathrm{Na} \cdot 2 \mathrm{H}_{2} \mathrm{O}\left(=\mathrm{Na}_{2} \mathrm{H}_{2} \mathrm{Y} \cdot 2 \mathrm{H}_{2} \mathrm{O}\right)$ を $80^{\circ} \mathrm{C}$ で乾燥し，銅と等モル数，すなわち $8.202 \mathrm{~g}$ を約 $200 \mathrm{ml}$ の水汇溶解した。両溶液を混合し, 希アンモ二 ア水または希塩酸で $\mathrm{pH}$ を約 4 亿調節したのち水で正 確に $1 l$ にうすめた。 との溶液 $1 \mathrm{~m} l$ は $10.35 \mathrm{mg} の$ $\mathrm{Na}_{2} \mathrm{CuY} \cdot 4 \mathrm{H}_{2} \mathrm{O}$ 亿相当する.

（2）同仁薬化学研究所製 Cu-EDTA $10 \mathrm{~g}$ 歨正確任 はかりとり，水汇溶解し，希塩酸または希アンモ二ア水 で $\mathrm{pH}$ を約 4 亿調節後水で正確に $1 l$ 亿うす女た。 ての 溶液 $1 \mathrm{ml}$ は $10.00 \mathrm{mg} の \mathrm{Na}_{2} \mathrm{CuY} \cdot 4 \mathrm{H}_{2} \mathrm{O}$ に相当す る.

インジウム標準溶液：横沢化学 K. K. 製金属インシ
ウム（純度 $99.95 \%$ 以上） $10.34 \mathrm{~g}$ 飞 $1: 1$ 塩酸を加元， 加熱溶解後水で正確に $1 l$ 亿うすめた ( $\mathrm{pH}$ 1.2). この 溶液を，キシレノールオレンジを指示薬として，標準 EDTA 溶液で滴定4)した結果， $1 \mathrm{ml}$ は $10.22 \mathrm{mg}$ の1 ンジウムに相当した。

楥衝溶液： $1 M$ 酷酸溶液と $1 M$ 酶酸ナトリウム溶液を いろいろの比で混合して，ちがった $\mathrm{pH}$ の溶液をつくっ た。

\section{3 定量方法}

$20 \mathrm{mg}$ 以下のインジウムを含むわずかに酸性の試料溶 液をビーカーにとり, Cu-EDTA 溶液 $10.0 \mathrm{ml}$ を加光， つぎに $\mathrm{pH} 4.3$ の $1 M$ 酶酸塭緩衝溶液 $2.5 \mathrm{ml}$ を加兄 る。必要ならば希アンモニア水また浠塩酸で $\mathrm{pH}$ を 4.3 亿調節し，水で正確に $25 \mathrm{~m} l$ にうすめる. 同様にし て試薬ブランクをつくる. $1 \mathrm{~cm}$ セルを用い, 試料溶液 を対照，すな⿰力口吸光度 0 にして，740 $\mathrm{m} \mu$ に打方試 薬ブランクの吸光度を測定する.

既知量のインジウムを用い，上と同じように操作して 検量線をつくる.

$$
\text { なお，実験はすべて } 16 〜 26^{\circ} \mathrm{C} \text { の室温で行なった。 }
$$

\section{4 結果および考察}

\subsection{Cu-EDTA の検量線}

EDTAによる銅の光度定量のための諸条件はNielsch と Böltz によって詳しく検討された1). それによれば， $\mathrm{pH}$ 4.75〜6.50 で $\mathrm{Cu}$-EDTA の吸光度は一定であり, $\mathrm{pH} 4.75$ 以下では吸光度は徐々に減少する. Nielsch によれば $\mathrm{pH} 3.2$ と $\mathrm{pH} 5.0$ における吸光度の比は約 $1: 1.16$ である。また銅の一定量をとり，EDTA を加 えていくと，1:1のモル比に打いて吸光度は最大とな り，そ玑以上 EDTA を加光ても吸光度は変わらない。

一般的にいって，EDTA は $\mathrm{pH}$ が高くなるとより多 くの金属イオンと反応する・したがって，インジウムの 場合もできるだけ低い $\mathrm{pH}$ で定量することが望ましい， $4 \cdot 2$ で述べるように, $\mathrm{pH}$ 3.2 5.3 でインジウムの検 量線は一定であった。参考のために， $\mathrm{pH} 4.3$ に打ける $\mathrm{Cu}$-EDTA の量と $740 \mathrm{~m} \mu$ における吸光度の関係老 Fig. 1 に示す. この場合水を対照にした. Cu-EDTA の分子吸光係数は 91 となる.

\section{$4 \cdot 2 \mathrm{pH}$ のインジウムの定量に及ぼす影響}

退色 (fading) 学利用する間接光度定量の方法は Reil-

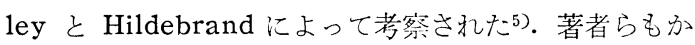
れらの方法のひとつに従い, 試料溶液炎対照, 寸なわち 吸光度を 0 として, 試薬ブランクの吸光度を測定するこ 


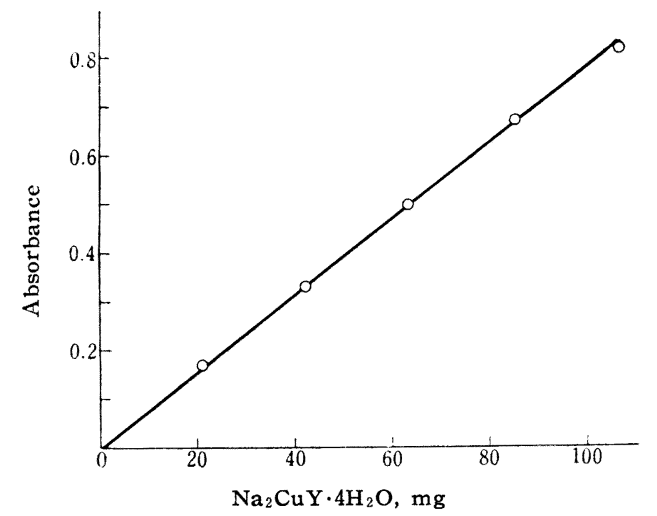

Fig. 1 Calibration curve for Cu-EDTA $\mathrm{pH} 4.3$

とにした．以下，本報告であらわされる吸光度はそのよ うにして測定されたものである。

インジウム $0,5,10,20 \mathrm{mg}$ をとり, $\mathrm{Na}_{2} \mathrm{CuY} \cdot 4 \mathrm{H}_{2} \mathrm{O}$ $106 \mathrm{mg}$ を加え, $\mathrm{pH} \mathrm{3.2,3.5,4.0,4.3,4.7,} \mathrm{5.3(ぞ}$ の場合も最終䣷酸塩濃度は $0.1 M$ ) における吸光度を測 定した結果, まったく同一の検量線が得られた.この場 合インジウムを含む溶液と試薬ブランクの $\mathrm{pH}$ は同じに した. pH 3.2 以下では, 䣷酸塩緩衝溶液は適当でない つて検討を行なわなかった。

\section{$4 \cdot 3$ 酢酸塩湿度の影響}

インジウム $10 \mathrm{mg}$ と $20 \mathrm{mg}$ をとり, 酢酸塭の濃度は 変化させるが $\mathrm{pH}$ は 4.3 に一定して, 吸光度の変化を調 ベた. との結果を Fig. 2 に示す. したがって, 酢酸塩 の濃度は $0.10 M$ に決めた。

\section{$4 \cdot 4 \mathrm{Cu}$-EDTA 濃度の影響}

インジウム $10 \mathrm{mg}$ と $20 \mathrm{mg}$ をとり, $\mathrm{pH} 4.3$ におい て Cu-EDTA の濃度を変えて吸光度の变化をみた。 $\mathrm{Na}{ }_{2} \mathrm{CuY} \cdot 4 \mathrm{H}_{2} \mathrm{O}$ が $90,100,110,120 \mathrm{mg}$ の範囲では まったく同一の検量線が得られた。

\section{5 吸光度の時間的変化}

インジウム $10 \mathrm{mg}$ と $20 \mathrm{mg}$ をとり，3 の定量方法に 従って得られた吸光度の時間的変化を Fig. 3 に示声.

室温 $24^{\circ} \mathrm{C}$ に拈いて, 吸光度は少なくとも 3 時間は安定 だ亦った。

\section{$4 \cdot 6$ インジゥムの検量線}

3 の定量方法によって得られたインジウムの検量線を Fig. 4 に示す. インジウムの適当な濃度範囲は 5〜20

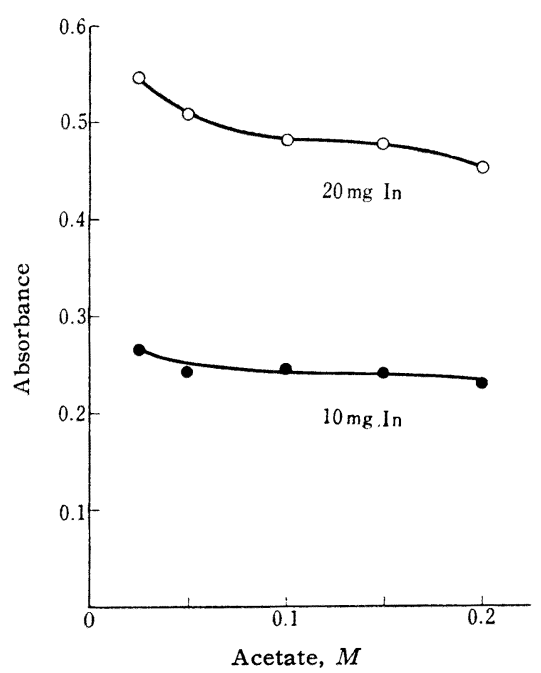

Fig. 2 Effect of acetate concentration $\mathrm{pH} 4.3$

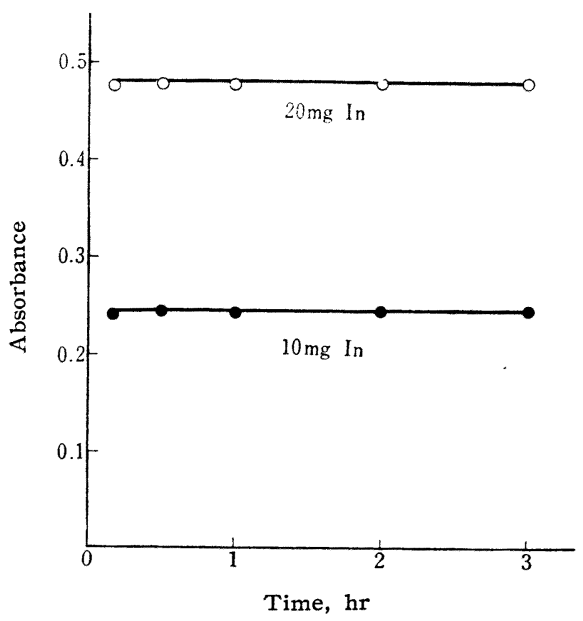

Fig. 3 Variation of absorbance with time

$\mathrm{mg}$ In $/ 25 \mathrm{ml}$ である. 検量線からインジウムのみかけ の分子吸光係数を求めると -65 となる.

試薬を混合し, $25 \mathrm{ml}$ に希釈後 $80^{\circ} \mathrm{C}$ の水浴中で 10 分 間加熱, 室温に泠却して吸光度を測定しても Fig. 4 と 同じ検量線が得られた。

インジウム $10.22 \mathrm{mg}$ を用い，3 の方法の再現性を調 ベた. 10回定量の結果は, 平均吸光度 0.233 , 標準偏差

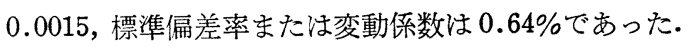

試薬を加える順序を逆にして, 最初に Cu-EDTA を 加え, つぎにインジウムを加えても結果に差は認められ なかった。 


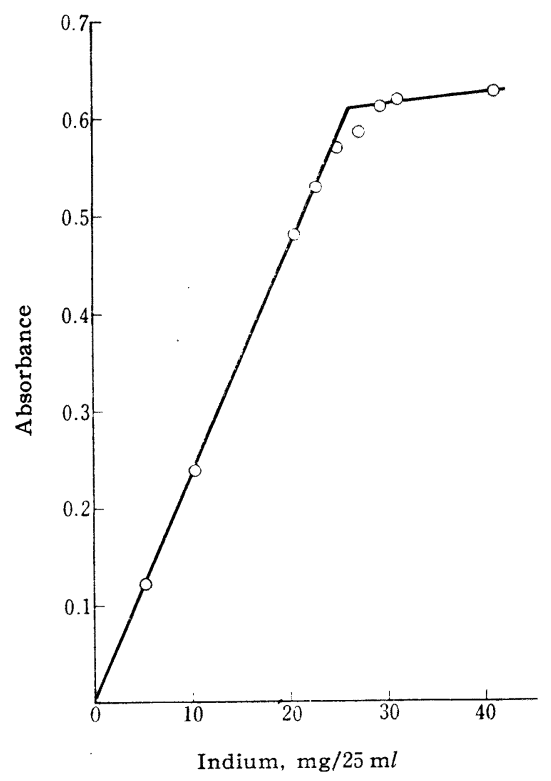

Fig. 4 Calibration curve for indium $\mathrm{Na}_{2} \mathrm{CuY} \cdot 4 \mathrm{H}_{2} \mathrm{O} \quad 106.5 \mathrm{mg}$

Fig. 4 はまたモル比法の実験結果とみることもでき る. Fig. 4 において, 検量線の折れる点を求めると 26.0 mg In となる.もし（1）式において反応が完全に右へ 進む，すなわちインジウムによる置換が完全に行なわれ るならば，理論值は $26.1 \mathrm{mg}$ In である.したがって置 換浪とえど完全であるとみなしてよい.

このことはまたつぎの実験によっても確かめられた。 すなわち (1) 式の右辺のものの吸光度が左辺のものの反 応により生じた生成物の吸光度と等しいという実験であ る.（1）式の右辺に対応させるために，インジウム(III) $26.1 \mathrm{mg}$ をとり，それと同じモル数の EDTA を加えて インジウム-EDTA を生成させ，さらに銅(II) $14.4 \mathrm{mg}$ と緩衝溶液を加えた．この溶液を対照として銅-EDTA 溶液の吸光度を測定して 0.630 の值を得た. この值は Fig. 4, $26.1 \mathrm{mg}$ のインジウムの吸光度（すなわちイン ジウム (III) $26.1 \mathrm{mg}$ に銅-EDT A と緩衝溶液を加え, この溶液を対照として銅-EDTA 溶液の吸光度を測定し たもので，(1) 式の左辺に相当する） 0.615 と実験誤差 内で一致する（容積はどの場合も $25 \mathrm{ml}$ ).

\section{$4 \cdot 7$ 共存元素の影響}

共存元素の影響を Table I に示す.用いた金属塩は 主として塩化物, 硝酸塩, または硫酸塩である.ビスマ ス(III), リン酸塩イオン注沈殿を生じ，妨害する.ジル
コニルイオン $\left(\mathrm{ZrOCl}_{2} \cdot 8 \mathrm{H}_{2} \mathrm{O}\right.$ を使用）は非常に妨害す る. みかけのキレート生成定数 $\left(\mathrm{pH} 4\right.$ における $\log K_{\mathrm{H}}$

Table I Determination of indium in the presence of foreign substances

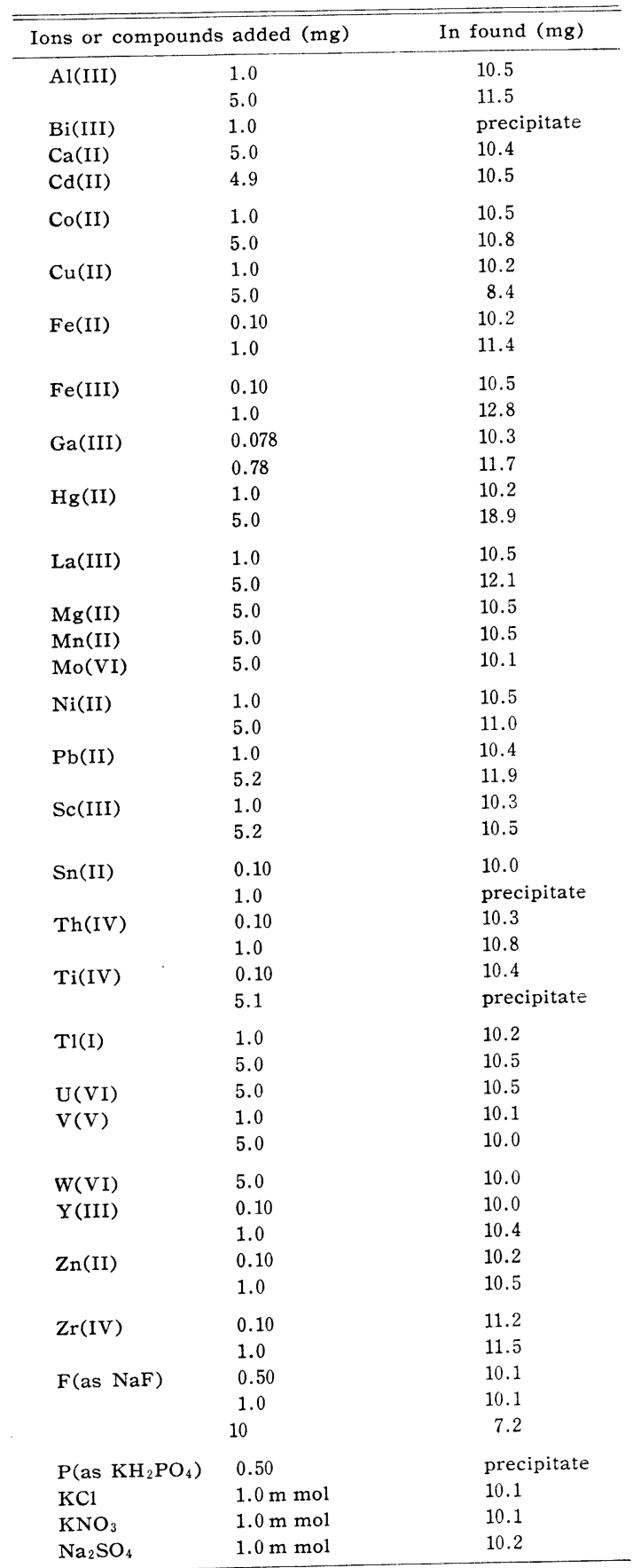

In(III) taken $=10.2 \mathrm{mg}$ 
は14.7) から考えると2)3)，スカンジウム (III) は妨害す ると予想されるが，妨害を認めることができなかった。

インジウムと同じ方法でトリウム (IV) の定量を試み たが，pH の影響が大きく，実際的な定量方法をつくる ことができなかった。

\section{交献}

1) W. Nielsch, G. Böltz : Z. anal. Chem., 143, 1 (1954).

2）上野景平：“キレート滴定法”， p. 31 (1960), (南江堂).

3) 上野景平 : 同上, p. 35.

4) J. Kinnunen, B. Wennerstrand : ChemistAnalyst, 46, 92 (1957).

5) C. N. Reilley, G. P. Hildebrand : Anal. Chem., 31, 1763 (1959).

$$
\text { is }
$$

Indirect spectrophotometric determination of indium with copper ethylenediaminetetraacetate. Hiroshi ONIsHi and Hitoshi NAGAI (Japan Atomic Energy Research Institute, Tokai-mura, Ibaraki- ken)

Copper ethylenediaminetetraacetate shows a light absorption at $700 \sim 750 \mathrm{~m} \mu$. The molar absorptivity is 91 at $\mathrm{pH}$ 4.3. At $\mathrm{pH} 4$, apparent formation constants, $\log K$, for $\mathrm{CuY}^{2-}$ and InYare 10.36 and 16.5 , respectively, where $Y$ is an ethylenediaminetetraacetate anion. Consequently, the following reaction (replacement or displacement) takes place : $\mathrm{In}^{3+}+\mathrm{CuY}^{2-} \rightleftarrows \mathrm{InY}^{-}+\mathrm{Cu}^{2+}$. Therefore, indium can be determined by measuring the decrease in absorbance of $\mathrm{CuY}^{2-}$ at $740 \mathrm{~m} \mu$.

The decrease in absorbance was measured by measuring the absorbance of a reagent blank containing $\mathrm{CuY}^{2-}$ alone against a sample solution containing indium. $\mathrm{CuY}^{2-}$ was prepared by mixing equal moles of $\mathrm{Cu}^{2+}$ and ethylenediaminetetraacetic acid disodium salt. Commercially available copper ethylenediaminetetraacetate also serves the purpose.

At $\mathrm{pH} 4.3$, using $100 \mathrm{mg}$ of $\mathrm{Na}_{2} \mathrm{CuY} \cdot 4 \mathrm{H}_{2} \mathrm{O}, 5$ to $20 \mathrm{mg}$ of indium in $25 \mathrm{ml}$ can be determined with good precision. Apparent molar absorptivity for indium is -65 .

(Received Nov. 30, 1963)

\title{
回転白金電極を用いるシアン酸塩の電流滴定
}

\author{
池田 早苗，西田 義郎*
}

\begin{abstract}
シアン酸塩と硝酸銀の沈殿反応に電流滴定法を適用するために種々検討し，1％程度の誤差でシアン 酸塩を定量する分析法を確立した。

定量操作は次のと扣りである． $0.001 \mathrm{~F}$ 程度のシアン酸塩を正確にはかりとり， $1 \mathrm{~F}$ 硝酸カりウム溶 液 $10 \mathrm{~m} l, 1 \%$ ゼラチン溶液 $2 \mathrm{~m} l$ およびメタノール $25 \mathrm{~m} l$ を添加し, 試料が炭酸塩を含むときには, さらに $1 \mathrm{~F}$ 硝酸バリウム浴液を $10 \mathrm{~m} l$ 加元ててれを完全に沈殿させ，水を加えて全容を $100 \mathrm{~m} l$ にして よく混合し， $5^{\circ} \mathrm{C}$ 以下に冷却したのち， $0.1 N$ 硝酸銀標準溶液を滴加しながら，回転微小白金電極を指 示電極, S.C.E. を対極として短絡滴定を行なう.

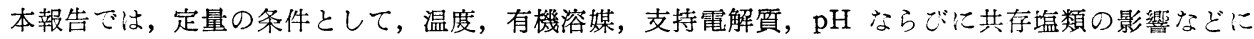
ついて検討した。
\end{abstract}

\section{1 緒 言}

シアン酸塩の定量方法として，(1) クロム酸カリウム を指示薬とする銀滴定法1)，(2) 吸着指示薬としてフル オレセインを用いる沈殿滴定法2)，(3) シアン酸銀とし て沈殿分離後, チオシアン酸塩法による銀イオンの定量 に基づく定量法122)，(4) シアン酸塩に硫酸銅(II) とピリ ジンを反応させ, ジシアナトジピリジン銅(II) 錯体の沈

$*$ 徳島大学工業短期大学部 : 德島市南常三島町 2 丁目
殿をつくりクロロホルムで抽出し，その中の銅(II)をヨ ウ素法により間接的に滴定する方法3)，(5) 硝酸銀溶液 による電位差滴定法4)，(6) 酸性においてシアン酸を分 解し，イオン交換法によってアンモニウムイオンを分離 して，ネスラ一試薬で発色させ比色する方法5)，（7）ジ シアナトジピリシンン銅 (II) 錯体のクロロホルム抽出液の 青色で比色定量する方法6), および (8) 塩酸セミカルバ ジドによる重量分析法门などが報告されている.

しかしながら，(1) 实よび (2) は反応生成物であるシ 